\title{
Analisis Status Gizi Balita di Kabupaten Sumenep Madura
}

\author{
Iffan Maflahah ${ }^{1,2}$ \\ ${ }^{1}$ Prodi Teknologi Industri Pangan Fakultas Pertanian Univ Trunojoyo Madura \\ ${ }^{2}$ Mahasiswa Pasca Sarjana Teknik Industri Institut Teknologi Sepuluh Nopember Surabaya \\ Email: iffanmaflahah@gmail.com
}

Naskah diterima 5 Januari 2018, Revisi 25 Februari 2019, Terbit 20 April 2019

\begin{abstract}
Abstrak
DOI: http://dx.doi.org/10.21107/pmt.v12i1.5177

Salah satu permasalahan kesehatan di Indonesia adalah kematian anak usia bawah lima tahun (balita). Sementara itu angka kematian dan stunting balita juga masih cukup tinggi. Masalah gizi dapat terjadi pada seluruh kelompok umur, bahkan masalah gizi pada suatu kelompok umur tertentu akan mempengaruhi pada status gizi pada periode siklus kehidupan berikutnya (intergenerational impact). Penelitian tentang identifikasi dan penanganan status gizi balita di Kabupaten Sumenep akan memberikan suatu arahan kebijakan dalam rangka penanganan berdasarkan status gizi balita. Tujuan dari penelitian ini adalah mengidentifikasi status gizi balita sehingga nantinya akan mampu menghasilkan suatu strategi penanganan status gizi balita yang tepat untuk lingkup Provinsi Jawa Timur, khususnya di Kabupaten Sampang dan Sumenep. Analisa data yang dilakukan pada penelitian ini adalah deskriptif dengan memanfaatkan data primer dan sekunder dari Dinas Kesehatan Kabupaten Sumenep didukung oleh data BPS dan instansi lainnya. Pada penelitian ini dilakukan pula pengumpulan data kuisioner dan selanjutnya strategi perencanaan penanganan status gizi balita disusun berdasarkan Analisa SWOT. Kasus gizi buruk di Kabupaten Sumenep dari tahun ke tahun mengalami penurunan. Pada tahun 2013 kasus gizi buruk mencapai 144, tahun 2015 menurun menjadi 71, dan pada tahun 2010 menurun menjadi 46 kasus, sedangkan pada tahun 2017 menurun menjadi 42. kecamatan-kecamatan di Kabupaten Sumenep bebas dari kasus gizi, kecuali Kecamatan Batuan, Kecamatan Sapeken dan Kecamatan Masalembu.
\end{abstract}

Kata kunci : balita, status gizi, perencanaan, penanganan, analisis SWOT

\section{PENDAHULUAN}

Masalah gizi pada balita menjadi masalah besar karena berkaitan erat dengan indikator kesehatan umum seperti tingginya angka kesakitan dan kematian bayi dan balita. Lebih jauh lagi, kerawanan gizi dapat mengancam kualitas sumber daya manusia di masa mendatang. Status gizi buruk pada balita dapat menimbulkan pengaruh yang sangat menghambat pertumbuhan fisik, mental maupun kemampuan berpikir yang pada akhirnya akan menurunkan produktivitas kerja. Balita hidup penderita gizi buruk dapat mengalami penurunan kecerdasan (IQ) hingga 10 persen. Keadaan ini memberikan petunjuk bahwa pada hakikatnya gizi yang buruk atau kurang akan berdampak pada menurunnya kualitas sumber daya manusia. Selain itu, penyakit rawan yang dapat diderita balita gizi buruk adalah diabetes (kencing manis) dan penyakit jantung koroner.
Dampak paling buruk yang diterima adalah kematian pada umur yang sangat dini (Samsul, 2011 dalam Sari 2014).

Mugianti et.al (2018) menyebutkan bahwa salah satu permasalahan kesehatan di Indonesia adalah kematian anak usia bawah lima tahun (balita). Angka kematian dan stunting balita di negara-negara berkembang khususnya Indonesia masih cukup tinggi. Salah satu penyebab yang menonjol diantaranya karena keadaan gizi yang kurang baik atau bahkan buruk. Kondisi gizi anak-anak Indonesia rata-rata lebih buruk dibanding gizi anak-anak dunia dan bahkan juga dari anak-anak Afrika. Tercatat satu dari tiga anak di dunia meninggal setiap tahun akibat buruknya kualitas nutrisi. Sebuah riset juga menunjukkan setidaknya 3,5 juta anak meninggal tiap tahun karena kekurangan gizi serta buruknya kualitas makanan. Badan kesehatan dunia (WHO) memperkirakan bahwa 54 persen 
kematian anak disebabkan oleh keadaan gizi yang buruk. Sementara masalah gizi di Indonesia mengakibatkan lebih dari 80 persen kematian anak (WHO, 2011).

Berdasarkan data BPS, tahun lalu angka balita lahir di Jatim sekitar 2,4 juta balita. Dari angka tersebut, 20 persennya menderita gizi buruk. Bahkan 38 persen dari angka tersebut mengalami kurang gizi. Tingginya angka gizi buruk di Jawa timur diduga merupakan akibat pola hidup yang kurang sehat dan informasi soal gizi yang salah. Untuk menekan angka kurang gizi, pemerintah sebenarnya telah mengupayakan untuk optimalisasi sebanyak 43 ribu lebih posyandu yang ada serta 1.400 posyandu mandiri yang tersebar di seluruh Jatim. Selain itu, Pos Kesehatan Pesantren, Polindes dan rumah sakit-rumah sakit yang ada di Jatim juga terus dioptimalkan kinerjanya.

Berbagai penelitian yang berkaitan dengan status gizi balita telah dilakukan, diantaranya Setianingsih (2013), Hermina (2011), serta Fitri (2012). Setianingsih (2013) melakukan klasifikasi terhadap status gizi balita di Jogjakarta dengan bagging regresi logistik ordinal. Hermina (2011) melakukan upaya pengelompokkan kabupaten/kota di berdasarkan status gizi buruk balita dengan analisis diskriminan. Sementara Fitri (2012) meneliti tentang faktor-faktor yang mempengaruhi angka harapan hidup, angka kematian bayi dan status gizi buruk dan stunting di Sumatra dengan analisis regresi multivariat. Inadiar (2010) meneliti tentang perbedaan pola asah, asih, asuh pada balita status gizi kurang dan normal dengan menggunakan uji Chi-square. Penelitian-penelitian tersebut sebagian besar tidak menekankan aspek humaniora. Aspek humaniora, seperti kekhasan budaya yang direpresentasikan kekhasan lokasi (kabupaten/kota) masih terbatas untuk dikaji. Oleh karena itu dalam penelitian ini akan dikembangkan pemodelan balita gizi buruk yang mengakomodasi adanya aspek perilaku masyarakat yang direpresentasikan dalam spasial (lokasi). Demikian juga mengingat tiap kabupaten/kota di Jawa Timur mempunyai otonomi daerah yang memungkinkan penentuan prioritas kebijakan kesehatan akan berbeda-beda (Setianingsih, 2013).
Masalah gizi dapat terjadi pada seluruh kelompok umur, bahkan masalah gizi pada suatu kelompok umur tertentu akan mempengaruhi pada status gizi pada periode siklus kehidupan berikutnya (intergenerational impact). Masa kehamilan merupakan periode yang sangat menentukan kualitas SDM di masa depan, karena tumbuh kembang anak sangat ditentukan oleh kondisinya saat masa janin dalam kandungan. Akan tetapi perlu diingat bahwa keadaan kesehatan dan status gizi ibu hamil ditentukan juga jauh sebelumnya, yaitu pada saat remaja atau usia sekolah. United Nations memfokuskan usaha perbaikan gizi dalam kaitannya dengan upaya peningkatan SDM pada seluruh kelompok umur, dengan mengikuti siklus kehidupan. Upaya perbaikan gizi dilakukan pada kelompok umur yang berbeda. Secara lengkap upaya perbaikan gzi berdasarkan umur dapat dilihat pada Gambar 1.

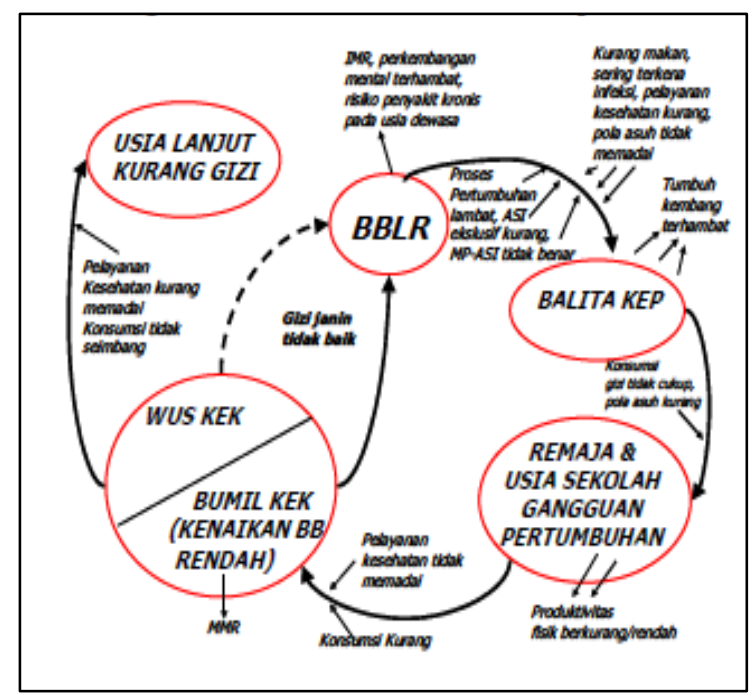

Gambar 1. Daur/Siklus Gizi

Penelitian tentang identifikasi dan penanganan status gizi balita di Kabupaten Sumenep akan memberikan suatu arahan kebijakan dalam rangka penanganan berdasarkan status gizi balita. Penanganan status gizi balita yang tepat akan memberikan dampak positif yaitu peningkatan perekonomian sebagai efek berkurangnya jumlah kurang gizi balita. Berkurangnya jumlah kurang gizi akan mampu meningkatkan produktifitas kerja. Dampak yang paling nyata dari penanganan status gizi yang tepat adalah berkurangnya kematian balita dan peningkatan kemampuan intelektualitas, 
berkurangnya biaya karena penyakit kronis serta meningkatnya manfaat "intergenerasi" melalui peningkatan kualitas kesehatan. Tujuan dari penelitian ini adalah mengidentifikasi status gizi balita sehingga nantinya akan mampu menghasilkan suatu strategi penanganan status gizi balita yang tepat untuk lingkup Provinsi Jawa Timur, khususnya di Kabupaten Sampang dan Sumenep.

\section{METODOLOGI}

Langkah-langkah/tahapan metode dalam penelitian ini adalah sebagai berikut:

\section{Inventarisasi Data}

Inventarisasi data ini pada dasarnya bertujuan untuk mengumpulkan atau mengkompilasi data dan informasi yang diperlukan. Data berasal dari instansi-instansi terkait, antara lain BPS, Dinas Kesehatan, BAPPEDA Kabupaten atau penelitian-penelitian terdahulu.

\section{Analisis}

Analisis dilakukan melalui kajian data dan informasi yang diperoleh, setidaknya memuat analisis :

- Analisis tingkat kesehatan masyarakat, terutama balita

- Analisis tingkatan status gizi balita

- Analisis peran pemerintah dan daerah dalam peningkatan gizi balita

3. Penyusunan siklus dan tahapan penanganan status gizi

Penyusunan siklus dan tahapan penanganan status gizi dilakukan dengan teknik kuesioner. Kuesioner diperuntukkan untuk responden yang berhubungan langsung dengan balita. Responden yang digunakan adalah kader posyandu, ibu yang memiliki balita, bidan dan petugas puskemas.

4. Penyusunan rumusan strategis dan rekomendasi dalam penanganan gizi buruk balita

Perumusan strategi penanganan dilakukan dengan menggunakan metode SWOT (Strength, Weakness, Oppurtunity, Threath). Penyebaran kuesiner untuk analisis SWOT dilakukan terhadap responden yaitu petugas kesehatan sebagai pakar gizi balita. Selain itu, kuesioner disebarkan kepada pegawai dinas kesehatan kabupaten untuk mendapatkan informasi tentang kebijakan pemerintah.

\section{HASIL DAN PEMBAHASAN}

- Analisis Status Gizi Balita Kab

\section{Sumenep}

Penentuan status gizi balita dapat dilihat dari tinggi badan per umur (TB/U), Berat badan per umur (BB/U), berat badan per tinggi badan (BB/TB. Kasus gizi buruk di Kabupaten Sumenep dari tahun ke tahun mengalami penurunan. Pada tahun 2013 kasus gizi buruk mencapai 144, tahun 2015 menurun menjadi 71, dan pada tahun 2010 menurun menjadi 46 kasus, sedangkan pada tahun 2017 menurun menjadi 42.

Kasus gizi buruk berdasarkan indeks BB/U Kabupaten Sumenep pada tahun 2013 terdapat 144 kasus, tahun 2015 menurun menjadi 71 kasus, dan pada tahun 2017 terdapat 46 kasus. Kasus gizi buruk pada tahun 2017 di Kabupaten Sumenep banyak ditemukan di Puskesmas Ganding (8 kasus), selanjutnya di Puskesmas Gili Genting (4 Kasus), Guluk - Guluk (4 kasus), dan Puskesmas Gapura (4 kasus). Selanjutnya, pada tahun 2013, jumlah balita yang berada dibawah garis merah adalah sebanyak 1.515 balita, sedangkan pada tahun 2015 mencapai 1.559 balita dan pada tahun 2017 mencapai angka 1.612 balita. Pada tahun 2017, balita dengan berat badan dibawah garis merah banyak terdapat di Desa Batuan, Kayuaro dan Gili Genting.

Secara umum, kecamatan-kecamatan di Kabupaten Sumenep bebas dari kasus gizi, kecuali Kecamatan Batuan, Kecamatan Sapeken dan Kecamatan Masalembu. Sedangkan pemberian ASI eksklusif pada tahun 2017 mencapai $25 \%$ (sejumlah 1.787 bayi) dari jumlah total bayi yaitu 7.059 bayi. Permasalahan pemberian ASI eksklusif perlu di tingkatkan, yaitu dengan cara meningkatkan kesadaran ibu yang mempunyai bayi. 
Tabel 1. Penemuan Kasus Gizi Buruk

\begin{tabular}{|c|c|c|c|c|}
\hline \multirow{2}{*}{ No } & \multirow{2}{*}{ PUSKESMAS } & \multicolumn{3}{|c|}{ JUMLAH KASUS GIZI BURUK } \\
\hline & & 2013 & 2015 & 2017 \\
\hline 1 & Pandian & 8 & 4 & 2 \\
\hline 2 & Pamolokan & 4 & 0 & 1 \\
\hline 3 & Batuan & 0 & 0 & 1 \\
\hline 4 & Kalianget & 9 & 4 & 3 \\
\hline 5 & Talango & 1 & 0 & 0 \\
\hline 6 & Manding & 5 & 1 & 0 \\
\hline 7 & Bluto & 3 & 0 & 1 \\
\hline 8 & Gili genting & 10 & 1 & 4 \\
\hline 9 & Saronggi & 3 & 3 & 0 \\
\hline 10 & Lenteng & 12 & 2 & 2 \\
\hline 11 & Moncek tengah & 0 & 0 & 0 \\
\hline 12 & Guluk-guluk & 6 & 5 & 4 \\
\hline 13 & Ganding & 13 & 4 & 8 \\
\hline 14 & Pragaan & 11 & 7 & 0 \\
\hline 15 & Ambunten & 16 & 11 & 4 \\
\hline 16 & Pasongsongan & 5 & 5 & 2 \\
\hline 17 & Dasuk & 0 & 0 & 0 \\
\hline 18 & Rubaru & 0 & 1 & 0 \\
\hline 19 & Batang-batang & 2 & 4 & 1 \\
\hline 20 & Legung timur & 3 & 1 & 1 \\
\hline 21 & Batu putih & 0 & 0 & 0 \\
\hline 22 & Dungkek & 7 & 1 & 1 \\
\hline 23 & Gapura & 5 & 7 & 4 \\
\hline 24 & Arjasa & 4 & 1 & 1 \\
\hline 25 & Kayuaro & 0 & 0 & 1 \\
\hline 26 & Sapeken & 10 & 3 & 3 \\
\hline 27 & Ra'as & 0 & 0 & 0 \\
\hline 28 & Gayam & 2 & 1 & 0 \\
\hline 29 & Nonggunong & 5 & 5 & 2 \\
\hline 30 & Masalembu & 0 & 0 & 0 \\
\hline & JUMLAH & 144 & 71 & 46 \\
\hline
\end{tabular}

Persentase kematian maternal di Kabupaten Sumenep pada tahun 2013 mencapai 17\%, tahun 2015 mencapai 32 $\%$ dan pada tahun 2017 mengalami penurunan $28 \%$. Sedangkan jumlah balita lahir mati pada tahun 2013 mencapai 163, tahun 2015 mencapai 202 balita dan pada tahun 2017 mencapai 171 balita.

Prevalensi balita gizi buruk merupakan indikator Millenium Development Goals (MDGs) yang harus dicapai disuatu daerah (kabupaten/kota) pada tahun 2015, yaitu terjadinya penurunan prevalensi balita gizi buruk menjadi 3,6 persen atau kekurangan gizi pada anak balita menjadi 15,5 persen (Bappenas, 2010). Pencapaian target MDGs belum maksimal dan belum merata di setiap provinsi. Besarnya prevalensi balita gizi buruk di Indonesia antar provinsi cukup beragam (Riskesdas, 2013).

Tabel 2. Prosentase Balita BGM

\begin{tabular}{|c|c|c|c|c|}
\hline \multirow{2}{*}{ NO } & \multirow{2}{*}{ PUSKESMAS } & \multicolumn{3}{|c|}{ JUMLAH } \\
\hline & & BALITA & BGM & $\%$ \\
\hline 1 & Pragaan & 4216 & 89 & 2,11 \\
\hline 2 & Bluto & 3573 & 24 & 0,67 \\
\hline 3 & Seronggi & 2828 & 99 & 3,50 \\
\hline 4 & Giligenting & 2008 & 75 & 3,74 \\
\hline 5 & Talango & 3285 & 58 & 1,77 \\
\hline 6 & Kalianget & 318 & 47 & 14,78 \\
\hline 7 & Pandian & 1983 & 14 & 0,71 \\
\hline 8 & Pamolokan & 3834 & 22 & 0,57 \\
\hline 9 & Batuan & 886 & 115 & 12,98 \\
\hline 10 & Lenteng & 2912 & 15 & 0,52 \\
\hline 11 & Moncek Tengah & 1834 & 27 & 1,47 \\
\hline 12 & Ganding & 2877 & 48 & 1,67 \\
\hline 13 & Guluk-Guluk & 421 & 49 & 11,64 \\
\hline 14 & Pasongsongan & 3445 & 80 & 2,32 \\
\hline 15 & Ambunten & 3181 & 42 & 1,32 \\
\hline 16 & Rubaru & 3073 & 34 & 1,11 \\
\hline 17 & Dasuk & 2398 & 99 & 4,13 \\
\hline 18 & Manding & 2172 & 36 & 1,66 \\
\hline 19 & Batuputih & 3537 & 20 & 0,57 \\
\hline 20 & Gapura & 3079 & 52 & 1,69 \\
\hline 21 & Batang-batang & 2788 & 58 & 2,08 \\
\hline 22 & Legung & 1464 & 26 & 1,78 \\
\hline 23 & Dungkek & 3014 & 32 & 1,06 \\
\hline 24 & Nonggunong & 132 & 16 & 12,12 \\
\hline 25 & Gayam & 2794 & 40 & 1,43 \\
\hline 26 & Ra'as & 29 & 25 & 86,21 \\
\hline 27 & Sapeken & 2762 & 28 & 1,01 \\
\hline 28 & Arjasa & 534 & 35 & 6,55 \\
\hline 29 & Kayuaro & 1484 & 268 & 18,06 \\
\hline 30 & Masalembu & 1742 & 4 & 0,23 \\
\hline & JUMLAH & 68603 & 1577 & 2,30 \\
\hline
\end{tabular}

Berdasarkan data riset kesehatan dasar (Riskesdas) 2010, secara nasional prevalensi balita gizi buruk sebesar 4,9 persen dan kekurangan gizi 17,9 persen. 
Rentang prevalensi BBLR (per 100) di Indonesia adalah 1,4 sampai 11,2, dimana yang terendah di Provinsi Daerah Istimewa Yogyakarta dan tertinggi di Provinsi Gorontalo. Provinsi Jawa Timur termasuk daerah dengan balita gizi buruk masih tergolong tinggi. Hal ini ditunjukkan dengan prevalensi gizi buruk sebesar 4,8 persen. Walaupun pada tingkat nasional prevalensi balita kurang gizi telah hampir mencapai target MDGs, namun masih terjadi disparitas antar provinsi, antara perdesaan dan perkotaan, dan antar kelompok sosial-ekonomi. Masih banyak bayi di bawah lima tahun di Jawa Timur yang mengalami gizi buruk (Surabaya Post, 2012). Dari total 1,29 juta balita di Jatim, sekitar 38\% diantaranya menderita gizi buruk. Masih banyak kasus gizi buruk di berbagai daerah di Jawa Timur itu bukan karena faktor kemiskinan, tapi lebih karena perilaku terhadap pola asup gizi makanan anak. Dari survei yang dilakukan menunjukkan 38 persen gizi buruk karena perilaku yang keliru terhadap pola asup gizi makanan pada anak, sedangkan 20 persen karena penyakit.

Menurut Dinas Kesehatan Jatim (2011) angka balita dengan gizi buruk sudah menurun sekitar $2 \%$ dibanding dengan sebelumnya. Untuk terus menekan angka tersebut, ibu-ibu harus diberi pemahaman yang komprehensif tentang pola asup gizi makanan anak. Salah satu upaya untuk menekan balita dengan gizi buruk itu, adalah dengan menambah jumlah Taman Posyandu. Keberadaan Taman Posyandu itu diharapkan bisa memberi pengetahuan tentang kebutuhan gizi anak. Sampai saat ini di Jawa Timur jumlah Posyandu yang tercatat ada 226.829 dan yang aktif sebanyak 226.227. Sampai pada 2013 mendatang ditargetkan ada 10 ribu Taman Posyandu berdiri di Jawa Timur.

Puskesmas merupakan ujung tombak pelayanan kesehatan termasuk juga peningkatan gizi balita. Sampai dengan tahun 2010, jumlah puskesmas di Provinsi Jawa Timur sebanyak 950 unit yang terdiri dari 467 puskesmas perawatan dan 483 puskesmas non perawatan yang tersebar di 622 kecamatan. Rasio puskesmas terhadap penduduk sebesar 2.50 per 100.000 penduduk, artinya setiap 100.000 penduduk dilayani oleh 2-3 puskesmas atau 1 Puskemas melayani 40.027 penduduk. Kondisi tersebut menunjukan bahwa jumlah puskesmas di Provinsi Jawa Timur masih kurang dari target nasional (1 puskesmas rata-rata melayani 30.000 penduduk).

Penimbangan berat badan balita merupakan salah satu cara yang paling efektif dalam memantau tingkat perkembangan gizi balita. Secara umum, kesadaran para orang tua dalam menimbang berat badan balita ke Posyandu atau Polindes meningkat pada periode waktu 2008-2010. Hal ini dapat dilihat pada meningkatkanya prosentase jumlah balita yang ditimbang sebesar $0.18 \%$. Secara umum, prosentase jumlah balita yang ditimbang untuk masingmasing kabupaten cukup bervariasi. Peningkatan prosentase jumlah balita yang ditimbang, meningkat cukup pesat di beberapa kabupaten misalnya : Bojonegoro, Lamongan, Malang, Kota Probolinggo dan Trenggalek. Sedangkan penurunan jumlah balita yang ditimbang menurun drastis di beberapa kabupaten lainnya, yaitu : Sumenep, Situbondo, Sampang, Probolinggo, Kota Mojokerto, Madiun dan Magetan. Hal yang cukup menarik terejadi di Kabupaten Lamongan dan Sumenep. Pada penjelasan sebelumnya, Kabupaten Sumenep dan Lamongan termasuk kabupaten dengan pertumbuhan balita cukup tinggi. Namun, hasil analisa selanjutnya menunjukkan bahwa terjadi penurunan prosentase balita yang ditimbang di Sumenep.

Pengukuran berat badan secara teratur dapat menggambarkan keadaan gizi anak, sehingga dapat dipakai sebagai salah satu pemantau pertumbuhan fisik anak. Berat badan merupakan ukuran yang sensitif yang sangat dipengaruhi oleh perubahan status gizi. Pada tingkat puskesmas atau lapangan, penentu status gizi yang umum dilakukan adalah dengan menimbang balita (berat badan per umur), kemudian indeks berat badan menurut umur tersebut dibandingkan dengan angka standar/anak yang normal. Tinggi badan anak tidak akan berkurang dengan menurunnya keadaan gizi anak tersebut (Robiah, 2007). Rangkaian garis pertumbuhan tersebut membentuk grafik pertumbuhan anak. 


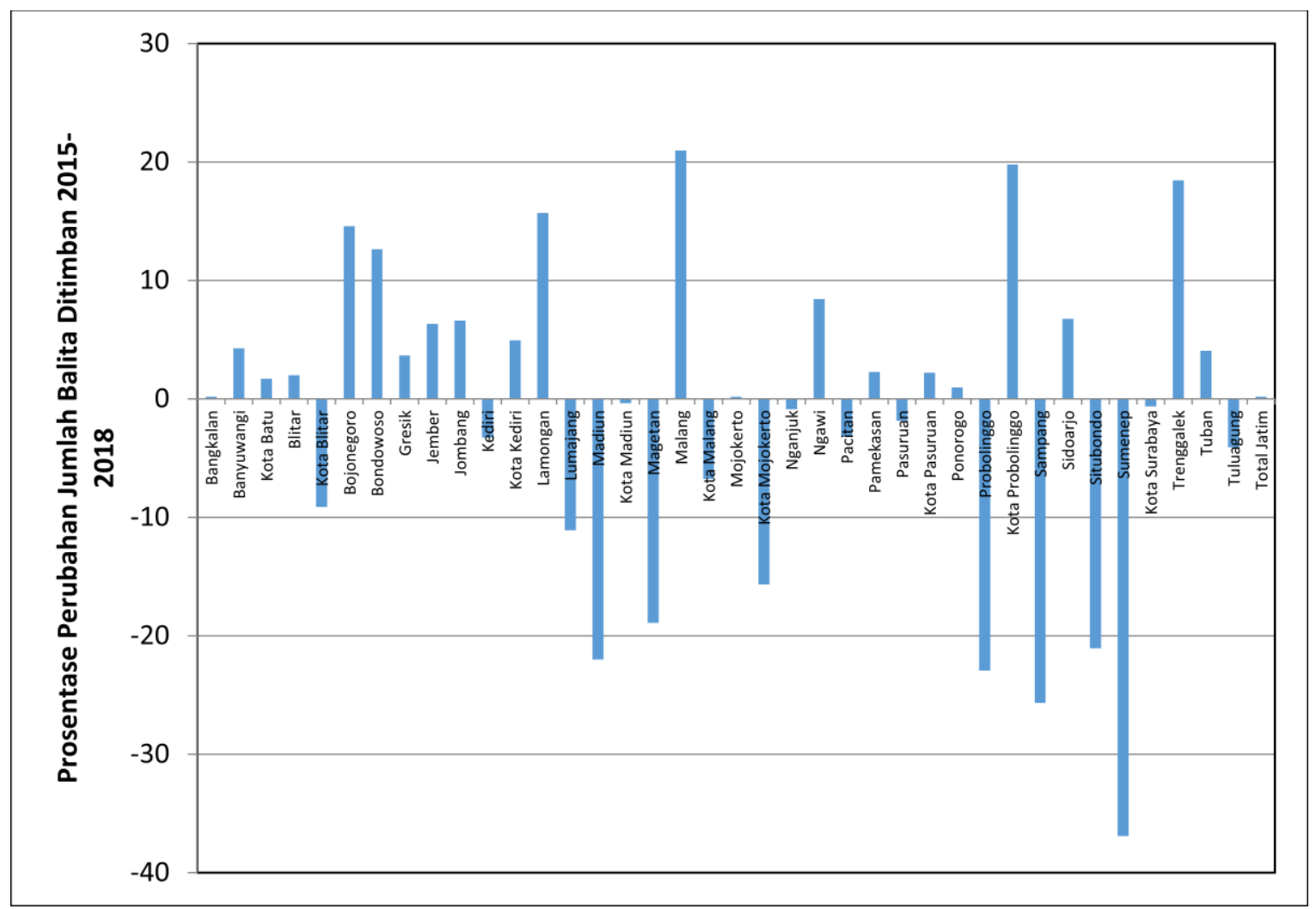

Gambar 2. Perubahan Jumlah Balita Ditimbang 2015-2018

Anak balita yang sehat atau kurang gizi secara sederhana dapat diketahui dengan membandingkan antara berat badan menurut umur atau berat badan menurut tinggi, apabila sesuai dengan standar anak disebut Gizi Baik. Kalau sedikit di bawah standar disebut Gizi Kurang, sedangkan jika jauh di bawah standar disebut Gizi Buruk. Bila gizi buruk disertai dengan tanda tanda klinis seperti ; wajah sangat kurus, muka seperti orang tua, perut cekung, kulit keriput disebut Marasmus, dan bila ada bengkak terutama pada kaki, wajah membulat dan sembab disebut Kwashiorkor. Marasmus dan Kwashiorkor atau Marasmus Kwashiorkor dikenal di masyarakat sebagai "busung lapar".Gizi buruk pada anak balita disebut juga kurang energi protein, ditandai dengan kondisi berat badan kurang dari berat seharusnya (berat badan pada KMS berada dibawah garis merah atau pita kuning bagian bawah). Penyebab timbulnya gizi buruk:

- Kurang makan makanan yang bergizi dalam waktu yang lama

- Menderita penyakit terutama penyakit infeksi
- Mengalami gangguan fungsi saluran pencernaan.

Makanan yang tidak cukup mengandung gizi dapat membuat balita rentan kekurangan gizi banyak faktor yang dapat menyebabkan balita menderita gizi buruk yaitu : sumber daya manusia, himpitan ekonomi, asupan gizi yang tidak seimbang, sering kita mendengar atau melihat di media elektronik dan media cetak. Dewasa ini masih banyak daerah daerah yang memiliki balita penderita gizi buruk, khususnya daerah daerah pada garis grafik kemiskinan yang cukup tinggi dan daerah pingiran atau pedalaman yang tidak terjangkau oleh sosialisasi hidup sehat pada masyarakat setempat.

Secara umum, terjadi penurunan jumlah kasus balita gizi buruk di Jawa Timur pada periode tahun 2013 - 2017. Tercatat pada tahun 2013 jumlah kasus balita gizi buruk di Jawa Timur mencapai angka 13.312 orang, sedangkan pada tahun 2017 jumlah tersebut menurun drastis menjadi sekitar 7.760 orang, atau mengalami penurunan sebesar 5.552 orang balita. Penurunan tertinggi terjadi di Kabupaten Malang. Pada tahun 2013 
tercatat sebanyak 1.489 kasus, sedangkan pada tahun 2017 hanya tercatat sebanyak 289 kasus saja. Selain itu, daerah yang berhasil menurunkan jumlah kasus balita gizi buruk adalah Surabaya Kota dan Kabupaten Bangkalan. Untuk Kota Surabaya, pada tahun 2013, jumlah kasus balita gizi buruk menurun tajam dari 2.068 kasus menjadi hanya 1.132 kasus. Sedangkan di Kabupaten Bangkalan, terjadi penurunan dari 927 kasus pada tahun 2013 menjadi hanya 11 kasus pada 2017. Akan tetapi, terdapat pula beberapa kabupaten yang mengalami peningkatan jumlah kasus gizi balita, seperti yang terjadi di Kota Probolinggo dan Kabupaten Tuban. Untuk Kabupaten Tuban, tercatat terjadi peningkatan sebanyak 162 kasus dari 375 kasus di tahun 2013 menjadi 537 kasus di 2017. Sedangkan di Kota Probolinggo, jumlah kasus gizi balita naik dari 186 kasus pada tahun 2013 menjadi 366 kasus pada tahun 2017.

\section{- Analisis Hasil Kuisioner}

Selain data-data dari Dinas Kesehatan Kabupaten Sumenep, pada penelitian ini juga dilakukan pengumpulan data menggunakan kuisioner. Tujuan dari pengumpulan data melalui kuisioner ini adalah untuk mengetahui peranan orang tua dalam menentukan jenis konsumsi asupan balita. Data kuisioner disebarkan kepada 78 sample/responden ibu rumah tangga Tabel dibawah ini menyajikan nilainilai statistik penting dari sample responden yang diambil.

Tabel 3. Statistik Sample Kuisioner

\begin{tabular}{|l|c|}
\hline \multicolumn{1}{|c|}{ Statistik } & Nilai \\
\hline Jumlah Sample ( $\mathrm{n})$ & 78 \\
\hline Rata-Rata Usia Sample (tahun) & 30.65 \\
\hline Usia Maximum Sample (tahun) & 51 \\
\hline Usia Minimum Sample (tahun) & 20 \\
\hline Standar Baku (tahun) & 6.19 \\
\hline
\end{tabular}

Berdasarkan data diatas, maka dapat terlihat bahwa rata-rata usia responden dalam pengumpulan data kuisioner adalah $30.65 \pm 6.19$ tahun dengan usia minimum adalah 20 tahun dan usia maksimum adalah 51 tahun. Responden paling banyak berusia 30 tahun. Jumlah responden terbanyak berikutnya adalah
28 tahun dan 26 tahun. Sementara itu, jumlah responden yang berusia 39-51 tahun terlihat cukup sama jumlahnya. Selanjutnya, sebagian besar responden (82.05\%) memiliki 1 orang balita yang diasuh dalam keluarga. Selain itu, responden yang memiliki 2 orang balita dalam keluarga adalah sekitar $15.38 \%$ dari seluruh responden dan $2.56 \%$ responden lainnya memiliki atau mengasuh balita sebanyak 3 orang dalam keluarganya (Gambar 3). Selanjutnya, apabila diperhatikan dari usia balita yang diasuh, maka terlihat bahwa sebagian besar responden mengasuh balita pada usia 11-15 bulan dan 21-25 bulan. Apabila dirata-rata, maka usia balita yang diasuh oleh responden dalam penelusuran data kuisioner ini adalah $23.01 \pm 0.15$ bulan .

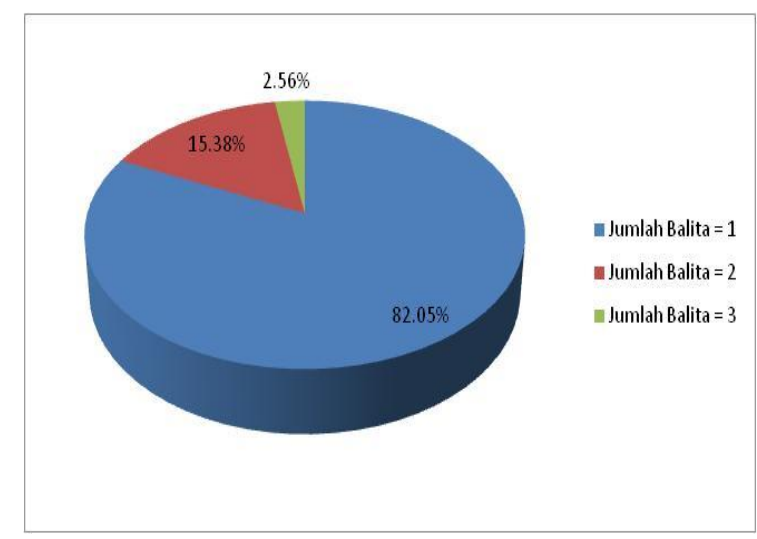

Gambar 3. Jumlah Balita yang Diasuh oleh Responden

Salah satu faktor yang diduga dapat mempengaruhi jenis dan jumlah asupan balita dalam rangka pencegahan gizi buruk adalah pengetahuan orang tua. Untuk mengukur tingkat pengetahuan orang tua, maka data tingkat pendidikan orang tua balita dapat dijadikan acuan. Pada peneluisuran data kuisioner, didapatkan informasi bahwa sebagian besar orang tua responden telah memiliki tingkat pendidikan yang cukup baik. Hal ini ditunjukkan oleh besarnya prosentase orang tua yang telah menamatkan pendidikan SMA $(43.59 \%$ ayah dan $50.00 \%$ ibu). Selain itu kurang lebih $29.49 \%$ ayah dan $23.08 \%$ ibu telah menamatkan pendidikan sampai Perguruan Tinggi. Sementara itu, jumlah orang tua yang tingkat pendidikannya rendah berkisar antara $15 \%$ sampai dengan $20 \%$. Data ini menunjukkan 
bahwa, sebagian besar responden telah memiliki tingkat pendidikan yang cukup tinggi, sehingga diduga bahwa pengetahuan akan kesehatan balita terutama tentang permasalahan gizi sudah dikenal dengan cukup baik. Anak balita merupakan kelompok yang menunjukkan pertumbuhan badan yang pesat, sehingga memerlukan zat gizi yang tinggi setiap $\mathrm{kg}$ berat badannya. Pendapatan suatu keluarga merupakan salah satu unsur yang dapat memperngaruhi status gizi. Hal ini menyangkut daya beli keluarga untuk memenuhi kebutuhan konsumsi makan. Masa balita sangat tergantung pada lbu atau pengasuhnya sehingga pertumbuhan dan perkembangannya sangat tergantung pada pola asuh gizinya. Oleh sebab itu, pada penelitian ini dilakukan pula penelusuran data terkait pendapatan keluarga responden. Hasilnya ditampilkan pada gambar berikut ini :

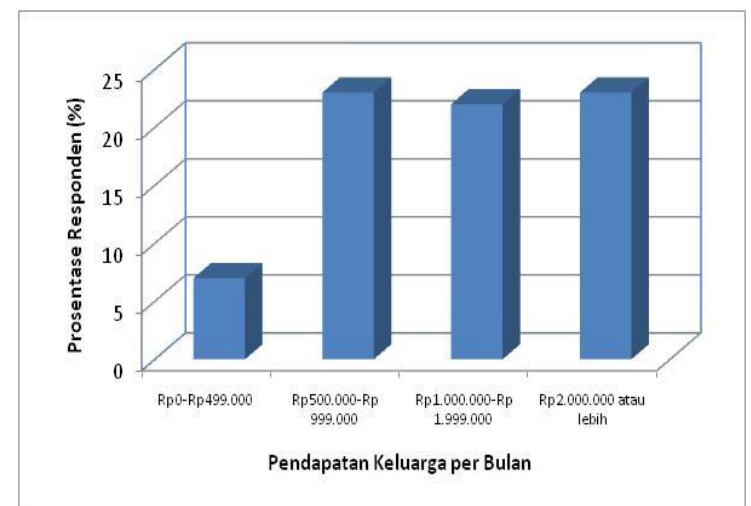

Gambar 4. Tingkat Pendapatan Responden

Pendapatan keluarga per bulan dapat mencerminkan tingkat ekonomi keluarga (Gambar 4). Pada penelusuran data kuisioner ini, didapatkan data bahwa sekitar $31 \%$ responden memiliki pendapatan $<$ Rp. 1.000 .000 per bulan. Sementara itu, responden yang memiliki penghasilan sampai dengan 2 juta per bulan adalah $20.05 \%$ dan responden dengan penghasilan >Rp.2.000.000 mencapai kurang lebih $23.15 \%$. Distribusi penghasilan seperti yang ditampilkan menunjukkan sebaran yang cukup seimbang antara responden berpenghasilan rendah dan sedang. Hal ini dapat terjadi karena survey dilaksanakan dengan mengambil sample di wilayah perkotaan dan pedesaan. Masa balita merupakan masa kehidupan yang sangat penting dan perlu diberikan perhatian yang serius. Pada masa ini berlangsung proses tumbuh kembang yang sangat pesat yaitu pertumbuhan fisik dan perkembangan psikomotorik (mental dan sosial). Pertumbuhan dan perkembangan balita sangat terkait dengan kondisi atau keadaan gizi balita tersebut serta pola asuh, termasuk pengasuh balita itu sendiri. Pada penelusuran data melalui kuisioner, dilakukan pula penggalian informasi mengenai pengasuh balita. Hasil nya disajikan pada gambar dibawah ini.

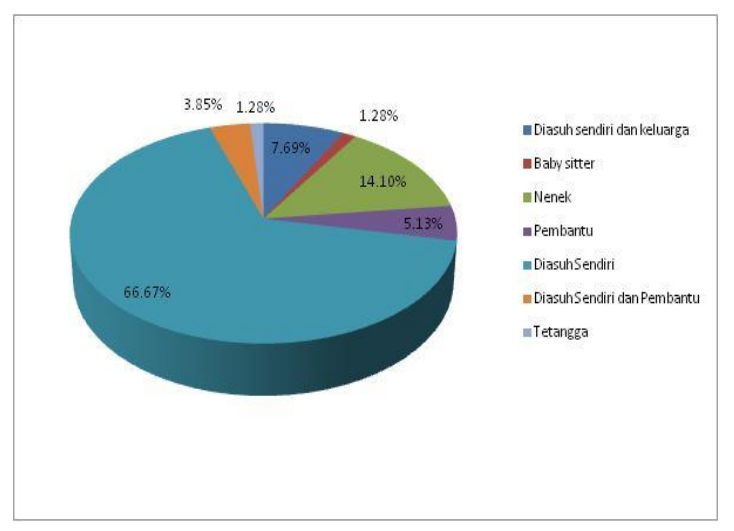

Gambar 5. Pola Pengasuhan Balita

Sebanyak $66.67 \%$ responden memilih untuk mengasuh balita sendiri. Responden yang mengasuh balita mereka sendiri kemungkinan adalah ibu rumah tangga yang tidak bekerja. Selain diasuh sendiri, para balita juga diasuh oleh pembantu rumah tangga. Jumlah responden yang melakukan hal tersebut hanya sekitar $5.13 \%$. Sementara itu, bantuan keluarga dalam mengasuh balita tampaknya juga banyak dilakukan. Hal ini terlihat dari sekitar $7.69 \%$ responden yang mengasuh balita dengan bantuan keluarga lainnya. Jasa baby sitter untuk mengasuh balita, ternyata hanya sedikit ditemui. Pada penelusuran data, hanya $1.28 \%$ responden yang memilih untuk menggunakan tenaga babi sitter untuk mengasuh balita mereka. Masalah gizi kurang dapat diperbaiki jika balita mendapatkan pola asuh yang baik. Hal ini sesuai dengan penelitian yang dilakukan oleh Hamidah (2006), yang menyatakan ada hubungan pola asuh gizi dengan status gizi. Dari hasil penelitian yang sudah dilakukan oleh Wigati (2009) dapat 
diketahui bahwa variasi makanan berhubungan bermakna dengan kejadian gizi buruk. Demikian juga ditemukan bahwa tipe pola asuh juga merupakan faktor yang berhubungan bermakna dengan kejadian gizi buruk Faktor tersebut tidak terlepas dari peran serta keluarga di dalam mengasuh untuk meningkatkan status gizi anak.

Pola asuh gizi adalah sikap dan perilaku ibu atau pengasuh lain dalam hal member makan, kebersihan, memberi kasih sayang, dan sebagainya berhubungan dengan keadaan ibu dalam hal kesehatan fisik dan mental (Soekirman, 2000). Praktek pola asuh gizi dalam rumah tangga biasanya berhubungan erat dengan faktor pendapatan keluarga, tingkat pendidikan dan pengetahuan ibu. Menurut Suhardjo (1986) anak-anak yang tumbuh dalam suatu keluarga miskin adalah paling rawan terhadap kurang gizi diantara seluruh anggota keluarga lainnya dan anak yang kecil biasanya paling terpengaruh oleh kurang pangan.

Dari paska lahir, berat bayi yang mencapai rata-rata $3 \mathrm{~kg}$, dalam kurun waktu satu tahun pertumbuhannya bisa mencapai sekitar $9 \mathrm{~kg}$. Oleh karena itu, sangatlah penting pemberian makanan pada bayi harus memenuhi syarat kebutuhan gizi. Pada prinsipnya, bayi memerlukan pemberian makanan secara bertahap. Dari tahap awal yang dimulai dari yang cair, lalu setengah padat, kemudian padat dan dilanjutkan makanan biasa berupa nasi dan lauk pauk. Tidak ketinggalan asupan air, vitamin, serta mineral untuk bayi haruslah cukup.

Walau demikian, kondisi bayi menentukan kesiapan menerima asupan makanan. Karena pada prakteknya pemberian makanan bersifat individual. Belum tentu semua bayi usia 4 bulan siap diberi bubur susu. Kondisi fisik bayi juga menentukan kesiapan menerima jenis asupan makanan. Kondisi fisik bayi meliputi berat dan tinggi badannya. Dimana dalam hal ini dokter anak-lah yang memiliki kompetensi khusus yang menilai. Oleh karena itu, penting sekali anak dipantau tumbuh kembangnya tiap bulan dari aspek keseluruhan. Dari tinggi badan bayi, berat badan bayi, jadwal pemberian imunisasi dan metode asupan pola makannya. Sesuaikan perkembangan fisik bayi dengan pola makannya, selama masih dalam pemantauan orangtua dan dokter anak, bayi akan mencapai proses tumbuh kembang secara optimal. Beberapa hal yang penting untuk diingat, seberapa banyak dan seberapa sering bayi makan, semuanya tergantung pada usia, tingkat pertumbuhan, berat badan, dan metabolisme. Dan semua itu tak sama antara satu bayi dengan bayi lainnya.

Mengingat pentingnya pengaruh jenis asupan terhadap pemenuhan gizi balita, maka dalam penelitian ini dilakukan pula pengumpulan data mengenai jenis asupan yang secara rutin diberikan orang tua atau pengasuh kepada balita. Hasilnya menunjukkan bahwa jenis asupan yang diberikan oleh sebagian besar responden adalah ASI ditambah dengan makanan lainnya (39.75\%).

Sementara itu, sebanyak $21.78 \%$ responden menyebutkan bahwa mereka hanya memberikan ASI saja sebagai asupan bagi balita. Selanjutnya susu formula menjadi pilihan asupan selanjutnya yang diberikan oleh responden kepada para balita. Jumlah responden yang memberikan susu formula adalah sekitar 17.95\%, sedangkan sekitar $20.51 \%$ responden telah memberikan asupan makanan kepada balita.

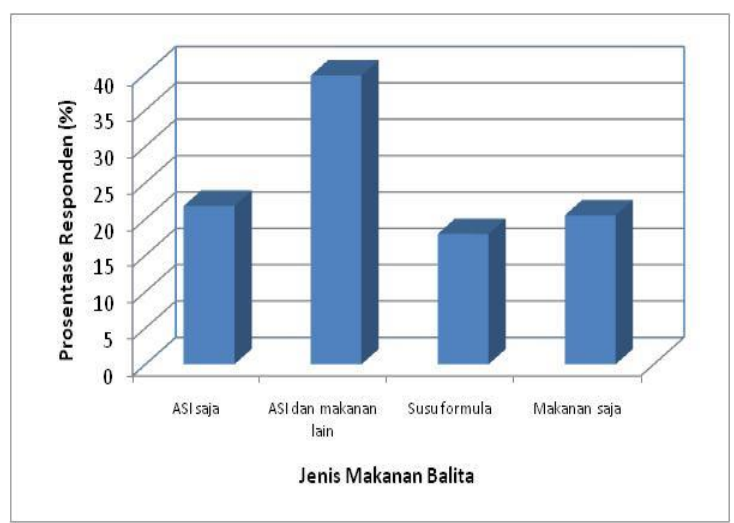

Gambar 6. Jenis Makanan/ Asupan Balita yang Diberikan para Responden

Berdasarkan gambar diatas, pada umumnya balita mulai diberikan makanan selain ASI pada usia 3-6 bulan. Hal ini terlihat dari prosentase jumlah responden yang menyebutkan hal itu, yaitu sekitar $53.84 \%$. Ada pula responden yang 
memberikan makanan selain ASI pada usia balita yang lebih muda yaitu pada kisaran usia 0-2 bulan. Responden yang menyatakan hal tersebut sekitar $20.51 \%$. Sementara itu, prosentase responden yang memberikanan makanan selain ASI pada usia $7-12$ bulan adalah $15.38 \%$ dan sekitar $8.56 \%$ responden memilih memberikanan makanan selain ASI pada usia balita diatas 12 bulan.

Selain asupan berupa ASI, balita juga memerlukan asupan berupa makanan. Pada penelitian ini didapatkan data bahwa setidaknya terdapat 3 jenis kelompok makanan yang diberikan oleh para lbu kepada balita sebagai makanan Non-ASI. Tiga jenis makanan tersebut adalah makanan bayi buatan pabrik, makanan bayi buatan sendiri (buatan rumah) dan MP-ASI dari Dinkes setempat. Hasil kuisioner meunjukkan bahwa 67.94\% makanan yang diberikan kepada balita adalah makanan buata rumah. Sedangkan sekitar $25.64 \%$ responden memberikan makanan buatan pabrik dan hanya sekitar $6.41 \%$ responden memberikan MP-ASI kepada para balita mereka.

Pemberian vitamin, mineral dan protein juga sangat dibutuhkan untuk menjaga kondisi gizi balita dalam keadaan yang baik. Sumber vitamin, protein dan mineral untuk balita dapat bersumber dari lauk pauk hewani, buah dan sayuran. Berdasarkan data kusioner tercatat bahwa sekitar $78.21 \%$ responden telah memberikan campuran lauk pauk hewani pada makanan balita dan kurang lebih $87.18 \%$ responden telah memberikan tambahan sayur dan buah pada makanan balita. Sekitar $51.28 \%$ responden menyatakan bahwa pemberian lauk hewani, sayur dan buah dilakukan setiap hari, sedangkan sisanya (48.72\%) memberikan lauk hewani, sayur dan buah tidak setiap hari.

Jumlah responden yang memberikan tambahan lauk hewani, sayur dan buah setiap hari berasal dari kelompok responden memiliki pendapatan antara Rp.1.000.000 - diatas Rp.2.000.000, yaitu sebanyak 25 orang responden. Sementara itu pada kelompok pendapatan yang sama, terdapat 20 orang responden yang ternyata tidak dapat memberikan lauk hewani, sayur dan buah pada balita.
Sedangkan pada kelompok responden yang memiliki pendapatan sampai dengan Rp.1.000.000 per bulan, jumlah yang memberikan lauk hewani, sayur dan buah setiap hari maupun tidak cukup berimbang.

\section{- Perencanaan Penanganan Status Gizi Balita}

Penentu kualitas sumberdaya manusia salah satunya adalah faktor gizi. Kecukupan gizi sangat dibutuhkan oleh setiap manusia, mulai dari dalam kandungan, bayi, balita , anak-anak, remaja, dewasa sampai usia lanjut. Calon ibu merupakan bagian usia yang harus mempehatikan masalah gizi. Calon ibu harus benar-benar menjaga kecukupan gizinya karena nantinya akan melahirkan bayi yang sehat. Kekurangan gizi menyebabkan kegagalan pertumbuhan fisik dan perkembangan kecerdasan, menurunkan produktivitas kerja dan menurunkan daya tahan tubuh, yang berakibat meningkatnya angka kesakitan dan kematian.

Terjadinya status gizi dimulai dari ada kegagalan produksi ataupun kegagalan panen. Kegagalan produksi akan menyebabkan krisis ekonomi terjadi. Kegagalan produksi dan didukung dengan adanya krisis ekonomi akan menyebabkan ketersediaan pangan di masyarakat menurun. Ketersediaan pangan menurun dapat di atasi dengan mendatangkan produk pangan dari luar, namun hal tersebut membutuhkan biaya yang cukup besar. Dengan adanya krisis ekonomi, otomatis pendapat masyarakat akan menurun, sehingga ketersediaan pangan rumah tangga akan menurun juga. Selain itu, pendapatan masyarakat menurun akan diimbangi daya beli yang menurun, sehingga tidak mampu untuk membeli makanan bergizi. Asupan makanan yang tidak bergizi akan menimbulkan infeksi terhadap tubuh manusia. Berdasarkan hasil kuesioner terhadap stakeholder maka diperoleh hasil tentang faktor faktor yang mempengaruhi status gizi balita di Kabupaten Sumenep adalah :

\section{Penyakit infeksi}

Penyakit infeksi yang banyak terjadi pada balita adalah penyakit diare dan ISPA. 
Kedua penyakit tersebut sangat rentan pada balita yang mempunyai status gizi buruk. Balita yang mengalami gizi buruk, membutuhkan perawatan, dan pasca perawatan kondisi kesehatan harus tetap diperhatikan. Balita yang menderita diare dan ISPA dalam waktu yang cukup lama akan menyebabkan berat badan akan terus menurun. Hal ini akan berpengaruh terhadap status gizinya. Selain diare, anak balita pasca perawatan gizi buruk juga rentan dengan penyakit ISPA. ISPA yang diderita oleh sebagian besar anak balita ini tergolong kategori ringan yaitu batuk disertai dengan tanda atau gejala seperti pilek, panas atau demam, dan serak.

\section{Gizi / asupan makanan}

Masalah utama disebabkan kekurangan atau ketidakseimbangan asupan energi dan protein. Masalah gizi makro bila terjadi pada wanita usia subur dan ibu hamil yang Kurang Energi Kronis (KEK) adalah berat badan bayi baru lahir yang rendah (BBLR). Bila terjadi pada anak balita akan mengakibatkan marasmus, kwashiorkor atau marasmic-kwashiorkor dan selanjutnya akan terjadi gangguan pertumbuhan pada anak usia sekolah.

\section{Pola asuh}

Pola asuh akan mempengaruhi status gizi, setiap keluarga diharapkan dapat menyediakan waktu, perhatian dan dukungan terhadap anak agar dapat tumbuh kembang dengan baik. Baik pertumbuhan fisik, mental maupun pertumbuhan sosial.

\section{Ekonomi}

Kondisi perekonomian masyarakat akan mempengaruhi daya beli masyarakat. Daya beli masyarakat terutama masyarakat miskin sedang mengalami penurunan, karena melambungnya harga sembako dan makanan bergizi seperti susu. Harga beras saat ini dengan kualitas beras standar mencapai harga di atas $\mathrm{Rp}$ 7.000,- Harga beras dengan standar sedang mencapai harga $R p 8.000$ - Rp 9000,-. Harga beras yang terus melambung, masyarakat miskin, nyaris tidak mampu untuk membelinya. Bagaimana mungkin masyarakat mau memiliki kesehatan yang berkualitas dengan asupan gizi yamg baik dan berkualitas jika harganya super mahal.

\section{Pelayanan kesehatan}

Sistem pelayanan kesehatan yang ada diharapkan dapat menjamin penyediaan air bersih dan sarana pelayanan kesehatan dasar yang terjangkau oleh setiap keluarga yang membutuhkan.

\section{Konsumsi / ketersediaan pangan}

Persoalan gizi buruk dan kurang gizi juga terkait dengan masalah ketahanan pangan. Kebijakan ketahanan pangan harus mendapat mendapat perhatian yang serius, yakni kebijakan untuk menjamin ketersediaan pangan yang mencukupi bagi penduduk. Ketersediaan pangan yang memadai ialah kualitas pangan itu sendiri. Artinya penduduk mengkonsumsi nutrisi-nutrisi mikro (gizi dan vitamin) yang mencukupi untuk hidup sehat. Kebijakan penting yang akan berpengaruh pada kualitas pangan dan nutrisi adalah upaya untuk melindungi sejumlah komoditas pangan, memperkenalkan program pangan tambahan setelah krisis, dan penyebaran dan pemasaran informasi mengenai nutrisi.

\section{Konsumsi makanan ibu hamil}

Konsumsi makanan yang dikonsumsi ibu hamil harus berkualitas, karena akan melahirkan bayi yang sehat.

\section{Masalah struktural}

Masalah gizi buruk atau kurang gizi yang menimpa sebagian masyarakat bukan sekedar masalah kultural masyarakat, tapi juga masalah struktural. Sebagian masyarakat yang terkena masalah gizi buruk atau gizi kurang bukan karena perilaku dan pola asuh yang salah semata, tapi juga karena kebijakan pembangunan, terutama di bidang kesehatan yang kurang berpihak pada mereka. Pertumbuhan perekonomian dan pembangunan hanya dinikmati oleh sebagian kecil orang atau kelompok menengah ke atas. Pertumbuhan dan pembangunan yang timpang berdampak langsung terhadap kualitas kehidupan masyarakat, terutama dalam hal kesehatan masyarakat. 
Tabel 4. Hasil Analisa SWOT

\begin{tabular}{|c|c|c|}
\hline $\begin{array}{c}\text { Analisa Swot Perencanaan } \\
\text { Penanganan Status Gizi Balita } \\
\text { Kabupaten Sumenep }\end{array}$ & $\begin{array}{l}\text { STRENGTH (Kekuatan) } \\
\text { 1. Adanya program pemerintah } \\
\text { yaitu : } \\
\circ \text { MP - ASI } \\
\circ \text { Pemberian } \\
\text { penyuluhan dan atau PMT } \\
\text { pemulihan } \\
\circ \text { Program ASI eksklusif } \\
\circ \text { Germas DARSI / KADARZI } \\
\text { (Keluarga Sadar Gizi) } \\
\circ \quad \text { Posyandu } \\
\circ \quad \text { Pendidikan gizi dan } \\
\text { kesehatan pada ibu - ibu } \\
\quad \text { yang mempunyai balita } \\
\text { Pemberian vitamin A dosis } \\
\text { tinggi } \\
\text { Lembaga yang terlibat aktif : } \\
\text { Dinas kesehatan,PKK, Dinas } \\
\text { Ketahanan Pangan, Bappeda, } \\
\text { Pemda, LSM, Dinas sosial, } \\
\text { Kader posyandu, PLKB, } \\
\text { Puskemas, Posyandu, Karang } \\
\text { taruna }\end{array}$ & $\begin{array}{ll} & \text { WEAKNESS (Kelemahan) } \\
\text { 1. } & \text { Pengetahuan orang tua rendah } \\
\text { 2. Perilaku orang tua } \\
\text { 3. Merubah pola pikir / kebiasaaan } \\
\text { orang tua/lingkungan/keluarga } \\
\text { dari balita } \\
\text { 4. Merubah pola asuh } \\
\text { 5. Masih kurangnya kesadaran } \\
\text { masyarakat terhadap kegiatan } \\
\text { program pemerintah } \\
\text { 6. Kesadaran ibu - ibu yang } \\
\text { mempunyai balita untuk ke } \\
\text { posyandu atau pelayanan } \\
\text { kesehatan jan yan tidak } \\
\text { Akses jalan yang } \\
\text { memadai untuk sampai ke } \\
\text { pelayanan kesehatan }\end{array}$ \\
\hline 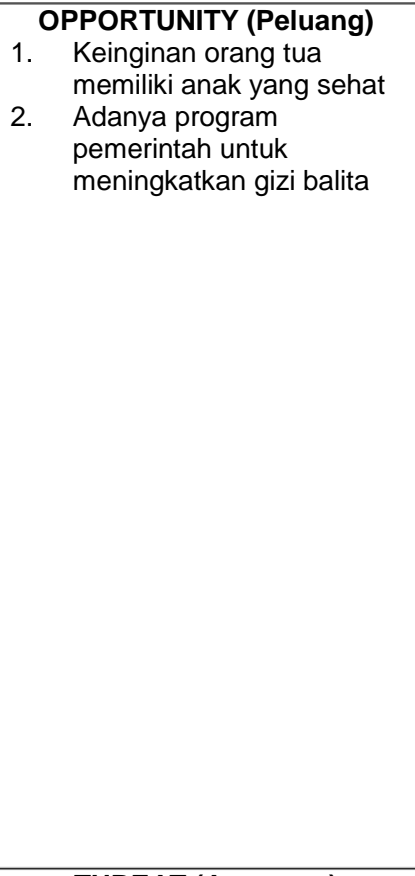 & $\begin{array}{l}\text { 1. Pendampingan pemberian } \\
\text { asupan gizi } \\
\text { 2. Mengaktifkan posyandu } \\
\text { 3. Mengoptimalkan surveilans } \\
\text { berbasis masyarakat melalui } \\
\text { SKDN, Sistem Kewaspadaan } \\
\text { Dini Kejadian Luar Biasa (SKD- } \\
\text { KLB) Gizi Buruk, dan Sistem } \\
\text { Kewaspadaan Pangan dan } \\
\text { Gizi (SKPG), untuk } \\
\text { meningkatkan manajemen } \\
\text { program perbaikan gizi. } \\
\text { Mewujudkan keluarga sadar } \\
\text { gizi melalui advokasi, } \\
\text { sosialisasi dan KIE gizi } \\
\text { seimbang. } \\
\text { Mengoptimalkan surveilans } \\
\text { berbasis masyarakat melalui } \\
\text { SKDN, Sistem Kewaspadaan } \\
\text { Dini Kejadian Luar Biasa (SKD- } \\
\text { KLB) Gizi Buruk, dan Sistem } \\
\text { Kewaspadaan Pangan dan } \\
\text { Gizi (SKPG), untuk } \\
\text { meningkatkan manajemen } \\
\text { program perbaikan gizi. }\end{array}$ & $\begin{array}{l}\text { 1. Mengembalikan fungsi } \\
\text { posyandu dan meningkatkan } \\
\text { kembali partisipasi masyarakat } \\
\text { dan keluarga dalam } \\
\text { memantau, mengenali dan } \\
\text { menanggulangi secara dini } \\
\text { gangguan pertumbuhan pada } \\
\text { balita utamanya baduta. } \\
\text { 2. Meningkatkan kemampuan } \\
\text { dan keterampilan SDM } \\
\text { puskesmas beserta } \\
\text { jaringannya dalam tatalaksana } \\
\text { gizi buruk dan masalah gizi } \\
\text { lain, manajemen laktasi dan } \\
\text { konseling gizi. } \\
\text { Akses jalan dan sarana } \\
\text { prasarana kesehatan dibuat } \\
\text { memadai }\end{array}$ \\
\hline 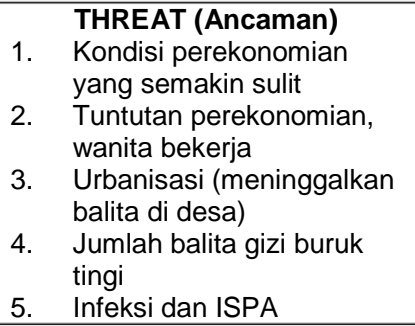 & 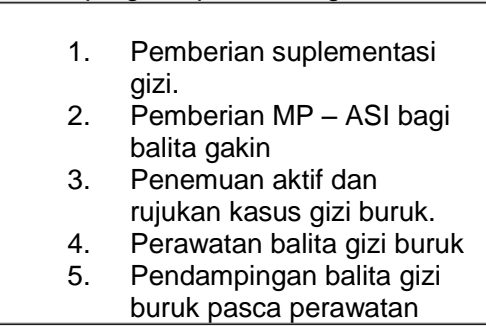 & $\begin{array}{l}\text { Menggalang kerjasama lintas sektor } \\
\text { dan kemitraan dengan masyarakat } \\
\text { beserta swasta/dunia usaha dalam } \\
\text { memobilisasi sumberdaya untuk } \\
\text { penyediaan pangan di tingkat rumah } \\
\text { tangga, peningkatan daya beli } \\
\text { keluarga, dan perbaikan pola asuhan } \\
\text { gizi keluarga }\end{array}$ \\
\hline
\end{tabular}

\section{KESIMPULAN}

Berdasarkan hasil Analisa SWOT pada strategi perencanaan penanganan status gizi balita di Kabupaten Sumenep sebagai berikut :

1.Mengembalikan fungsi posyandu dan meningkatkan kembali partisipasi masyarakat dan keluarga dalam memantau, mengenali dan menanggulangi secara dini gangguan pertumbuhan pada balita utamanya baduta.

2. Meningkatkan kemampuan dan keterampilan SDM puskesmas beserta jaringannya dalam tatalaksana gizi 
buruk dan masalah gizi lain, manajemen laktasi dan konseling gizi.

3.Menanggulangi secara langsung masalah gizi yang terjadi pada kelompok rawan termasuk keadaan darurat melalui suplementasi zat gizi mikro, MP-ASI, makanan tambahan dan diet khusus.

4. Mewujudkan keluarga sadar gizi melalui advokasi, sosialisasi dan KIE gizi seimbang.

5.Mengoptimalkan surveilans berbasis masyarakat melalui SKDN, Sistem Kewaspadaan Dini Kejadian Luar Biasa (SKD-KLB) Gizi Buruk, dan Sistem Kewaspadaan Pangan dan Gizi (SKPG), untuk meningkatkan manajemen program perbaikan gizi.

6. Mengembangkan model intervensi gizi tepat guna yang evidence based.

7.Menggalang kerjasama lintas sektor dan kemitraan dengan masyarakat beserta swasta/dunia usaha dalam memobilisasi sumberdaya untuk penyediaan pangan di tingkat rumah tangga, peningkatan daya beli keluarga, dan perbaikan pola asuhan gizi keluarga.

\section{DAFTAR PUSTAKA}

Fitri. 2012. Berat Lahir Sebagai Faktor Dominan Terjadinya Stunting Pada Balita (12-59 Bulan) di Sumatera (Analisis Data Riskesdas 2010). Thesis. Fakultas Kesehatan Masyarakat. Universitas Indonesia.
Hermina, P.S. 2011. Gambaran Keragaman Makanan dan Sumbangannya Terhadap Konsumsi Energi Protein Pada Anak Balita Pendek (Stunting) di Indonesia. Puslitbang Gizi dan Makanan Badan Litbangkes Kemenkes RI. Jurnal Badan Litbangkes, Vol 39 No 2.62-73 pp.

Mugianti, S.,Mulyadi, A.,Anam, A.K \& Najah. Z.L. 2018. Faktor Penyebab Anak Stunting Usia 25-60 Bulan di Kecamatan Sukorejo Kota Blitar. Jurnal Ners dan Kebidanan. Vol 5 No 3.

Riskesdas. 2013. Riset Kesehatan Dasar Tahun 2013. Badan Penelitian dan Pengembangan Kesehatan. Kementerian Kesehatan RI.

Sari, D.N.I. 2014. Hubungan Pemberian MP-ASI dengan Status Gizi pada Anak Usia 1-2 Tahun di Wilayah Kerja Puskesmas Minggir Sleman Jogjakarta. Naskah Publikasi. Sekolah Tinggi IImu Kesehatan Aisyiah. Jogjakarta.

Setianingsih, H. 2013. Hubungan Perilaku Ibu dengan Pemberian MP-ASI degan Status Gizi Balita Usia 6-24 Bulan di Posyandu Kelurahan Wirobrajan. Jogjakarta. Skripsi. Sekolah Tinggi IImu Kesehatan Aisyiah. Jogjakarta. 
2 Jurnal Pamator 